\title{
PRODUCT DESIGN FOR SUSTAINABILITY: DEVELOPMENT OF A NEW GRADUATE COURSE IN INDUSTRIAL DESIGN Çağla DOĞAN*
}

Received: 13.01.2012, Final Text: 02.07.2012

Keywords: product design for sustainability; graduate design education; design-based approach for sustainability; product lifespan.
* Department of Industrial Design, Faculty of Architecture, METU, Ankara, TURKEY.

\section{INTRODUCTION}

The course entitled 'Product Design for Sustainability' was opened in the Department of Industrial Design at the Middle East Technical University for graduate level students in the spring semester of 2011. Throughout the course, the nature of sustainability is examined so as to allow students to develop an understanding of its applicability to the area of product design and development. A useful base knowledge of the subject is established through an initial literature review of selected papers related to product design for sustainability and design critique of mass-produced products, and the application of that critique to design explorations for lighting products.

The course offers a unique perspective by examining the nature of objects and their relationship to sustainability within a design-centred approach. An important component of the course is the conceptual notions of sustainable products, for which the students prepare their design concepts for class presentation. They present a summary of the 'sustainable design considerations' that they deem significant from the literature review, such as localisation; increased product lifespans; and engaging, enabling and evolving design in relation to product value, longevity and meaning. The students re-contextualise objects with a consideration of the ramifications of the design concepts through sketches, mock-ups and working models, and present their reflections on, and insights into, the design process. A potential product category for the design explorations and critiques of the students is lighting. The students present an assessment of their proposed designs based on product design for sustainability, including their key conclusions and findings. This paper presents the design outcomes and insights into development that have resulted from offering this graduate course. 
1. The main structure of the graduate course is based on the interdisciplinary graduate course offered by Professor Stuart Walker in the Faculty of Environmental Design at the University of Calgary in Canada from 2004 to 2006 entitled "Sustainable Product Design". The author developed the course "Product Design for Sustainability" through a design-based approach and a comprehensive literature review of the topics emerged through the doctoral studies (Doğan, 2007).

\section{PRODUCT DESIGN FOR SUSTAINABILITY COURSE}

The 'Product Design for Sustainability' (1) course aims to provide insights into product design, sustainability and contemporary issues by addressing three strands of sustainability, being: ecological, ethical and economic. It includes a review of various systems thinking processes and design-based approaches as they relate to sustainability and product design (see Table 1). The graduate level course aims to: give the students a better understanding of both systems thinking and design-based approaches (e.g. The Natural Step, Integrated Scales of Design and Production, etc.); provide a medium for critical discussion and creative reflection on these approaches; and develop and assess current design considerations for sustainability (e.g. increased product lifespans, localisation, effective use of resources, product maintenance, repair and upgrade, etc.).

\section{Session 1 Introduction}

The first session offers an introduction to the course 'Product Design for Sustainability', and includes a general overview of topics, readings, timelines and course assignments. A lecture is given introducing the ecological principles.

\section{Session 2 Sustainability and Design (systems thinking-based approaches)}

The second session presents an overview of systems thinking approaches related to sustainability and design within historical and contemporary contexts, and explains the three strands of sustainability: ecological, ethical and economic. The principles of Ecological Footprint and Life Cycle Assessment (LCA) approaches focus particularly on quantitative calculations of the environmental impacts of materials and production processes (Robèrt et al., 2002). Design-based approaches are also introduced in the second session, including biomimicry (i.e. design innovation inspired and informed by nature) and Droog design (i.e. design explorations that contest the understanding of material culture in terms of reuse and re-contextualisation) (Ramakers, 2002; Benyus, 1997). A lecture on systems thinking-based approaches is followed by a video presentation, namely Biomimicry in Action by Janine Benyus (2009).

\section{Session 3 Sustainability and Design - The Natural Step}

The Natural Step (TNS) approach, the four systems conditions and a workshop module for industrial designers are introduced in this session.

\section{Session 4 Sustainability Scenarios - Product Service Systems (PSS) and Social Innovation}

The fourth session covers exemplary cases regarding product-service-systems, sustainable solutions and scenarios for urban life. This session includes a video presentation on social innovation by Ezio Manzini (2010) and a class presentation by the students on selected papers (Manzini, 2007; Morelli, 2007).

\section{Session 5 Behavioural Change and Eco Feedback}

Selected papers on behavioural change and eco-feedback (Chapman, 2009; Lilley, Lofthouse and Bhamra, 2005) are presented by the students.

\section{Session 6 Sustainable and Responsible Consumption}

The sixth session presents an overview of various approaches towards sustainable consumption (e.g. voluntary simplicity, eco villages, etc.) and product design. Presentations are made of selected papers with a particular focus on sustainable and responsible consumption (Marchand, Walker and Cooper, 2010; Cooper, 2005), and a presentation based on a PDD study on sustainable consumption (Marchand 2008). 
Table 1. Product Design for Sustainability Course Outline.

\section{Session 7 Integrated Scales of Design and Production - Localisation and Sustainability}

This session explains the implications of localisation for product design and sustainability, and provides an introduction to the "Integrated Scales of Design and Production" (ISDPS) approach facilitating design solutions for product maintenance, repair, re-use and upgrade (Doğan, 2007). Design critique presentations: A lecture on the ISDPS approach is followed by class presentations of design critiques of selected mass-produced products prepared by the students.

\section{Session 8 Research through Design - Sustainable Design Considerations}

This session focuses on sustainable design considerations and product design explorations, and their implications for design and aesthetics (Walker, Doğan and Marchand, 2009; Walker, 2009a), and includes a video presentation by Stuart Walker (2009b) followed by a class discussion.

\section{Session 9 Evolving and Engaging Design for Sustainability}

This session involves student presentations of selected papers (Walker, 2010a; Walker, 2010b) discussing such sustainability concepts as evolving and engaging designs.

\section{Session 10 Sustainability and Design Education}

The tenth session looks at design education for sustainability, drawing upon exemplary cases from industrial design studio projects. A lecture on design education cases is followed by a class discussion (Coşkun and Doğan, 2010a; 2010b; Doğan 2010).

\section{Sessions 11-13 Conceptual Notions of Sustainable Products}

The development of design concepts are based on the design considerations that emerged in the previous sessions.

\section{Sessions 14 Final presentations}

The final session is devoted to the final presentation of the students' design concepts and their design reflections on the process, and an assessment of their design concepts that takes into account the selected sustainable design considerations.

The course comprises fourteen weeks or sessions, and utilises a broad range of media for teaching (e.g. seminars, video presentations, class discussions, conceptual notions of products and class presentations), as presented in Table 2 . The course has been structured around conversation of design and sustainability, and so active class participation is expected. The course evaluation and sessions are based on the following media (Table 2):

\begin{tabular}{|l|l|l|l|l|l|l|l|l|l|l|l|l|l|l|}
\hline & 1 & 2 & 3 & 4 & 5 & 6 & 7 & 8 & 9 & 10 & 11 & 12 & 13 & 14 \\
\hline $\begin{array}{l}\text { Presentations of } \\
\text { selected papers }\end{array}$ & & & & & & & & & & & & & & \\
\hline $\begin{array}{l}\text { Video } \\
\text { presentations }\end{array}$ & & & & & & & & & & & & & & \\
\hline $\begin{array}{l}\text { Lectures and } \\
\text { class discussions }\end{array}$ & & & & & & & & & & & & & & \\
\hline $\begin{array}{l}\text { Design critique of } \\
\text { product }\end{array}$ & & & & & & & & & & & & & & \\
\hline $\begin{array}{l}\text { Conceptual } \\
\text { notions }\end{array}$ & & & & & & & & & & & & & & \\
\hline $\begin{array}{l}\text { Final } \\
\text { presentations }\end{array}$ & & & & & & & & & & & & & \\
\hline
\end{tabular}

Table 2. Demonstration of the main components and media for each session throughout the course. 
The product design for sustainability course comprises the following main assignments:

- Product design for sustainability - initial literature review

Presentations of selected papers to the class with a written summary (sessions 4, 5, 6 and 9)

- Design critique of a mass-produced product from a product design for sustainability perspective

Presentation to the class with a written summary (session 7)

- Conceptual notions of sustainable products (sessions 11, 12 and 13)

Final presentation and term paper (sessions 14)

\section{PRODUCT DESIGN FOR SUSTAINABILITY - INITIAL LITERATURE REVIEW}

The objective of the literature review is to gain insights into the field of product design for sustainability, in which students are required to share their findings from a selection of readings provided by the course instructor. For the class presentation, each class member is asked to read one (or more) of the selected papers, highlighting the main points, conclusions and examples contained in each paper and summarizing its essential aspects as related to the topics set out in the course outline - this takes the form of a roundtable discussion. For each paper, in addition to the class presentation, students prepare a one-page summary sheet in a given format for inclusion in a course bibliography. The written summary is approximately three hundred words, and summarizes the main points of the article, its arguments and conclusions, and includes selected keywords that characterise the content of the article. The selected articles have as their main focus sustainable production and consumption, systems thinking approaches and product design for sustainability, as detailed in the course outline. The literature review phase of the course helps the students better understand the design considerations for sustainability. The students explore the emerging sustainability considerations (e.g. increased product lifespans, localisation, effective use of resources, product maintenance, repair and upgrade, etc.) throughout the course sessions. Along with the lectures, this phase is a preparation for the next ones which are the design critique of a mass-produced product and the conceptual notions of sustainable products.

The initial lectures have a particular focus on topics related to ecological and sustainability principles, such as the Okala Ecological Design guide and impact factors, and the Natural Step Framework (TNS) related to the product design and development process. The main principles of ecology are introduced in the early sessions, exploring the relationships between organisms and their environment, including land, water, air, organisms, material cycles, habitats, etc. Ecology and its resources are finite and act as a closed system encompassing the eco-systems on which the current global economy is completely dependent, such as air, land, water, food and waste processing (Hawken, 1993). Within mature self-sufficient ecosystems, species remain within stable populations (e.g. coral reefs and ancient forests, containing diverse organisms and plants). Immature ecosystems, in contrast, contain a small number of quickly and competitively growing species, and use most of their readily available energy and resources for 
growth, thus limiting the diversity of other species (Carson, 1962). If the population of any organism exceeds the carrying capacity of a habitat, the ensuing depletion of natural resources, and the spread of disease or excessive waste will have a detrimental effect on all organisms that exist within that eco-system, even reaching to the point of their extinction.

Human impacts on ecology include resource depletion, waste and pollution, all of which have a significant impact on biological cycles. According to a recent study, over half of the accessible or available fresh water, and 80 percent of the world's fish stocks have been fully or over exploited (UN Water, 2011; UN FAO, 2010). Environmental economist Herman Daly (1996) raised concerns regarding these pressing environmental issues in the early 1990s, coining the term 'sustainable economy', meaning the use of only available solar energy and renewable resources within a 'steady-state economy or system'. According to Daly, unlimited growth is incompatible with the earth's system. A 'steadystate economy' would consume a non-growing amount of resources, like mature eco-systems, to ensure sustainability. Within the three domains of sustainability, some attention has been given to environmental stewardship, mainly as a result of standards and legislation; whereas social well-being and cultural diversity are generally overlooked in conventional economic models. Consequently, economic viability within the context of economic progress has become a traditional priority in business models that does not take into consideration the ecological and social implications of waste, pollution and resource depletion.

\section{Ecological Footprint and Assessment Tools}

The world is warming at an alarming rate. Environmental scientists acknowledge an increase of between one-and-a-half and six degrees Celsius by 2100 (IPCC, 2007), with the global air temperature anomaly reaching almost a half degree Celsius in 2010, making it the third warmest year on record according to the Climatic Research Unit (2011). The sectors of housing, transport and food are responsible for almost 80 percent of $\mathrm{CO} 2$ emissions in the European Union, with the developed nations being most at fault, and industrially developed countries have been shown to produce several times the $\mathrm{CO} 2$ emissions of non-industrially developed countries (Fuad-Luke, 2009). The Ecological Footprint (2010) concept emerged out of theories developed by William Rees and Mathis Wackernagel in the mid 1990s as an assessment tool for the measurement of sustainability and increasing consumption. It is based on the idea that human impact and reliance on the natural world can be calculated based on the amount of resources consumed per given area of land. To find out the biggest consumers of resources and to discuss alternative solutions to limit the areas of consumption, students use the ecological footprint calculator as an exercise, and share their findings, comments and insights with the rest of the class. Although this is a rough and simple calculation, it helps students understand how these types of tools can be developed further for use by industrial designers. For instance, the students concluded that a qualitative assessment would be useful to them in relating or matching these areas of footprint or consumption with product design-related solutions. Furthermore, the inclusion of locally relevant data in an ecological footprint assessment would also be valuable, since these calculations have been based generally on European databases, leading to further generalisations in resource consumption and limiting the use of locally relevant data and solutions. 
Assessment tools aimed at enabling incremental environmental changes or improvements are adopted by large-scale design and manufacturing companies. For instance, the Cradle to Cradle (C2C) principle aims to minimise the consumption of resources and ecological damage based on the idea of 'waste equals food', in which the product parts are re-integrated into the design and production processes through the recycling of materials (McDonough and Braungart, 2002). By focusing only on technical issues both social and environmental issues, which are inherently interconnected, are on the whole overlooked. The notion of sustainability embraces bottomup approaches through which knowledge is accessible by all parties or shareholders (e.g. designers, manufactures at all scales of production, consumers, etc.) as an open source data system. Contemporary tools and LCA methods act as closed systems, in which it is not viable to access the source of data, nor assess the impact of a product. As can be understood from the class discussions, the students believe that these sources are to a great extent inaccessible, meaning that eco-design alternatives and related solutions appear to be limited to the large-scale design and manufacturing companies.

\section{Okala Ecological Design Course}

One session of the course is dedicated to the Okala eco-design impact factors developed particularly for design education and industrial designers. The Okala Ecological Design course guide was developed by design educators in the United States, where Okala (oqala) implies 'life sustaining energy' in the Native American language (White, St. Pierre and Belletire, 2009), and is derived from the tradition of respect for the natural environment and its inhabitants through the conservation of both its renewable and non-renewable resources. The Okala guide has a particular focus on the quantitative assessment of environmental impacts throughout the product lifespan (e.g. design, production, use and disposal of a product). Eco-design requires a rethinking and redesigning of the whole product lifespan, in which designers can play a role in reducing the environmental impacts (e.g. resource depletion, contamination/pollution of air, water and soil, etc.) of each phase of the product lifespan.

According to the eco-design approach, these impacts can be minimised, if environmental considerations are taken into account at the outset of the idea generation and design detailing phases of the product design and development process. Each phase of the product lifecycle requires additional materials and energy, and results in emissions affecting air, water and soil. To calculate these impacts, the Okala guide is built on the impact factors of materials and related processes based on a specific Life Cycle Assessment (LCA) method and a database developed by the U.S. Environmental Protection Agency (EPA). Okala impact factors are based on an optimisation and quantification of the impacts of a product, for which an exemplary assessment is made of a radio casing in the Okala guide, without taking into account the internal electronic components (e.g. circuitry, switches, wires, etc.). However, based on the class discussions, analysing and assessing the environmental impacts of only the radio's plastic casing and offering a recycled plastic alternative is considered to be a limited approach, as it may be more beneficial to consider the product as a whole. This assessment does not address the social aspects of sustainability, and does not, on the whole, encourage designers to think of sustainable alternatives in terms of scale of production, product value, longevity, design aesthetics and localisation. It also fails to question 
the rationale behind the selection of materials for the product and the environmental implications of the production processes.

\section{The Natural Step (TNS)}

Another perspective is introduced by The Natural Step (TNS) foundation, which is an international organisation proposing four system conditions to help rethink and stabilise conditions in the global ecosystem (TNS, 2011). This approach provides a general framework for businesses to make changes in their design and manufacturing processes. The TNS highlights four system conditions:

- Use of renewable materials from the Earth: Substances from the Earth's crust must not systematically accumulate in the biosphere. For example, renewable metals, fossil fuels and other minerals must not be extracted and processed at a faster rate than their regeneration.

- Eliminating toxic substances/materials: Substances must be able to be fully broken down and re-integrated into the cycles of nature. Materials with toxic content must not be deposited in the Earth's crust.

- Both quality and quantity of nature: The physical foundation for diversity and productivity of nature must be protected to ensure that the productive surfaces of nature are not deteriorated in either quality or quantity, allowing for the renewal of natural resources.

- Social aspect: There needs to be a fair and equitable allocation of resources to meet basic human needs through their most effective use. The social aspects of sustainability aim to strengthen participation by encouraging local knowledge and empowerment in order to better address issues (e.g. the destruction of habitats, pollution and climate change).

The TNS approach describes how the decline in living systems is in conflict with the increasing demand for products. Accordingly, developing and implementing solutions would be viable through addressing the system conditions, since the TNS framework considers the deterioration of natural resources in terms of both quality and quantity. This would have implications on society (e.g. health of workers, working conditions, cultural diversity, etc.), ecology (i.e. species, land, water, air, etc.) and businesses (i.e. consumer awareness and responsiveness, government regulations, environmental standards, etc.).

A session of the course is dedicated to the application of the TNS framework through a workshop module that follows four main phases: understanding, assessing, envisioning and implementing. Firstly, the students, in two groups, choose a product (e.g. lighting or food packaging). Secondly, they use the template sheets and record the chosen product's relationship to each of the TNS conditions based on the questions provided with each condition template sheet. Thirdly, they note the items that occur on more than one sheet through cross comparison and referencing. The workshop module of the TNS four conditions is presented on separate worksheets. The students have difficulty in relating these worksheets due to the separate representation of each condition, even though they are interrelated. Each worksheet also includes a list of questions related to each condition, which helps the students raise questions in terms of the implications of externalised material sourcing and production, and 
alternative materials and production processes. However, the worksheet is not specifically designed to help the design students in the idea generation phase, in that it only emphasises the redesign of an existing product through incremental changes or improvements, rather a total rethinking of the product.

Product obsolescence can result from technological and aesthetic aspects, as well as built-in obsolescence. Functionality is only part of the reason for disposing of a product, and sometimes only a very small part. Accordingly, electronics are to a great extent thrown away while still functioning, meaning that it is important not only to understand the primary function of a product, but also how we relate to it (Chapman, 2005; Verbeek and Kockelkoren, 1997). Pressing environmental issues and their social implications need to become the focal consideration and practice of design, production, use and post-use of products. Not only design and production, but also the consumption side of sustainability need to be considered simultaneously. Tim Cooper (2005) proposes the term 'efficacy', taking into account both sufficiency (i.e. slowing down the rate of consumption of resources) and efficiency (i.e. more productive use of resources) when prolonging product lifespans. The effective use of natural resources would not itself lead to sustainability; however, through class discussions, the students can understand the need for design solutions that reconsider and reconnect efficiency and sufficiency respectively for both the production and consumption sides of sustainability.

Fuad-Luke defines the term design activist as someone who is a 'facilitator', 'creator', 'co-author', 'co-creator' and 'happener' (i.e. make things happen) through the use of the strength of design for the greater benefit of people and nature, and who enables social, institutional, environmental and economic change (Fuad-Luke, 2009). The main role of the designer has become to raise awareness; to find new ways of making and producing through more exploratory and design-based approaches, such as ecoeffectiveness and facilitation for co-creation and localisation; and to encourage new sustainable and responsible consumption patterns for product value, longevity and meaning (Walker, 2011; Doğan and Walker, 2008; Walker, 2006a; 2006b; Cooper, 2005; Papanek, 1999). As Chapman and Gants state (2007), the aim of design is to ensure the empowerment and incorporation of social and environmental values throughout the whole lifespan of a product.

\section{DESIGN CRITIQUE OF A MASS-PRODUCED PRODUCT FROM A 'PRODUCT DESIGN FOR SUSTAINABILITY' PERSPECTIVE}

Drawing on the findings of previous sessions, the students propose a comprehensive definition of the term 'Product Design for Sustainability' (PDS) and they prepare a design critique of a common mass-produced product, including a presentation of the product, for class discussion. The keywords for the design critique session may include mass-produced objects, design, aesthetics, ethical issues, product disposal, externalised material sourcing, production, etc. The Submission format is a two-page design critique that includes the definition of the product's sustainability and a visual representation of the selected product. The design critique of a product is based on sustainable design considerations, with an emphasis on integrated scales of design and production, which implies: 
- blending scales of design and production;

- aesthetically adaptable and tailored to local/regional materials and manufacturing capabilities for post-use services at the local batchproduction scale, such as maintenance, repair, re-use and upgrade;

- accessibility and authenticity through the facilitation of user comprehension and engagement;

- continuously evolving products, generating variety and diversity.

Product design for sustainability addresses both the environmental and socio-cultural implications of the current industrial system, which requires a rethinking of current production and consumption patterns (or systems) at both a societal and individual levels. As exemplary cases, some of these aspects are emphasised during the design critiques of products (e.g. electrical kettle, MP3 music player and bedside table lamp) selected and presented by the students:

Localization: Proposing increased localisation for production and post-use of products would reduce the negative environmental impact, and would contribute to the development of diverse local economies. Products are made up of several parts made from different materials and using different production techniques. The production and assembly of electrical and electronic components are mainly outsourced to Asia, where labour costs are low, and the parts are assembled and distributed globally to retail stores on a large scale. Consequently, the environmental and social impacts of extraction and process of raw materials are mainly externalised. For instance, while an electric kettle or a bedside table lamp may be stamped "made in Turkey", not all of its components are necessarily manufactured at a regional or local scale. Accordingly, the environmental and social impacts of manufacturing and transportation processes cannot be evaluated due to the unavailability of assessment data.

Increased product lifespans: User involvement in the product design and development process leads to a better understanding of real user needs and preferences, which in turn leads to increased product lifespans and locally tailored design solutions. The casings of the products exemplified here, being an electric kettle, an MP3 player and a bedside table lamp, are mainly made of plastic with polished surface finishing applications, which in fact decreases the product lifespan of the product. Contrary to gracefully aged materials, polished and even surface finishing applications to plastics lead to aesthetic obsolescence, since the casing or housing quickly becomes worn as a result of scratches to the product's surfaces. For an electric kettle, the main plastic body is not easy to clean, and may become discoloured after several uses, considerably decreasing the lifespan of the product.

Product post-use: Accessible and open-source design solutions facilitate a sharing of knowledge and empower people at the local batch-production scale for the repair, re-use and recovery of product parts. For an MP3 player, the LCD screen and the re-chargeable batteries contain toxic materials such as lead and cadmium, and although the battery may be rechargeable, it should still be disposed of correctly at the end of its lifespan. While the LCD screen may be broken, the product may retain its primary function. Technological obsolescence also leads to product disposal within a short period of time. The inaccessibility of its inner electronic parts does not allow product maintenance, repair or upgrade. The assembly of an electric kettle involves quite a few plastic parts that are 
not clearly labelled, which in turn leads to difficulties in disassembly and post-use processes, and shortens its lifespan. Although, the MP3 player or the bedside lamp has similar disadvantages and problems in terms of product post-use, the end user in this case, may still retain the product and continue to use it, if it has inherited value and meaning as a gift.

Effective Use of Resources: Small household appliances, electronics and electrical products, such as kettles, music players and lamps, may make our lives more convenient, but they tend to consume more resources during use, and local user needs, tastes and preferences are generally overlooked. For instance, the size of the water reservoir in a kettle is of considerable size. If the water level indicator is not located properly, it may not allow the user from effectively using the resources. Similarly, the control and display on a kettle needs to be visible from every angle to provide feedback, since the user may sometimes forget whether it is turned on or off. The water may evaporate, resulting in a potential fire hazard and the kettle consuming more energy and water than it requires. From the design critiques, it can be concluded that the real needs and preferences of the end user need to be fully considered in the design and development of the products. Product design for sustainability would enable the active participation and involvement of users, allowing an integration of local tacit knowledge and skills into the design and development process.

The design critique of mass-produced products encourages students to reflect on sustainability approaches related to the product design and development process, considering the entire lifespan of the product. This process also helps them to factor sustainability considerations into product design, such as localisation, material selection and sourcing, resource consumption, user participation and feedback, product maintenance, repair and upgrade, and product attachment through considering concurrently the environment, society and economy. The design critiques also serve as a preparation phase for the next and final phase of the course, namely the conceptual notions of sustainable products.

\section{CONCEPTUAL NOTIONS OF SUSTAINABLE PRODUCTS}

The third component of the course includes conceptual notions of sustainable products, a class presentation and a term paper. The students prepare their ideas for a class presentation that is to include:

- A summary of sustainable design considerations that they deem significant from the literature review, including references and design critique sessions.

- Redefining and re-contextualising objects with consideration of the ramifications of the design concept, presented through sketches, mock-ups, preferably working model(s), and reflections on and insights into their design process. The students may make their own choice of products, but a potential product category is lighting, which can be discussed and confirmed during the design session. Other potential product categories may include small-scale electronics such as music players, clocks, etc. through which the students can explore various design considerations by means of developing working models.

- An assessment of the design solution based on the product design for sustainability, including key conclusions and findings. 
Figure 1. The Tippy lighting concept by Aykut Coşkun.

Figure 2. The Withy lighting concept by Çiğdem Güneş.

Figure 3. The Light-mill lighting concept by Anil Ilgaz.

Figure 4. The Nest lighting concept by Ayşegül Özbayis.

Figure 5. The Light in Heart lighting concept by Senem Turhan
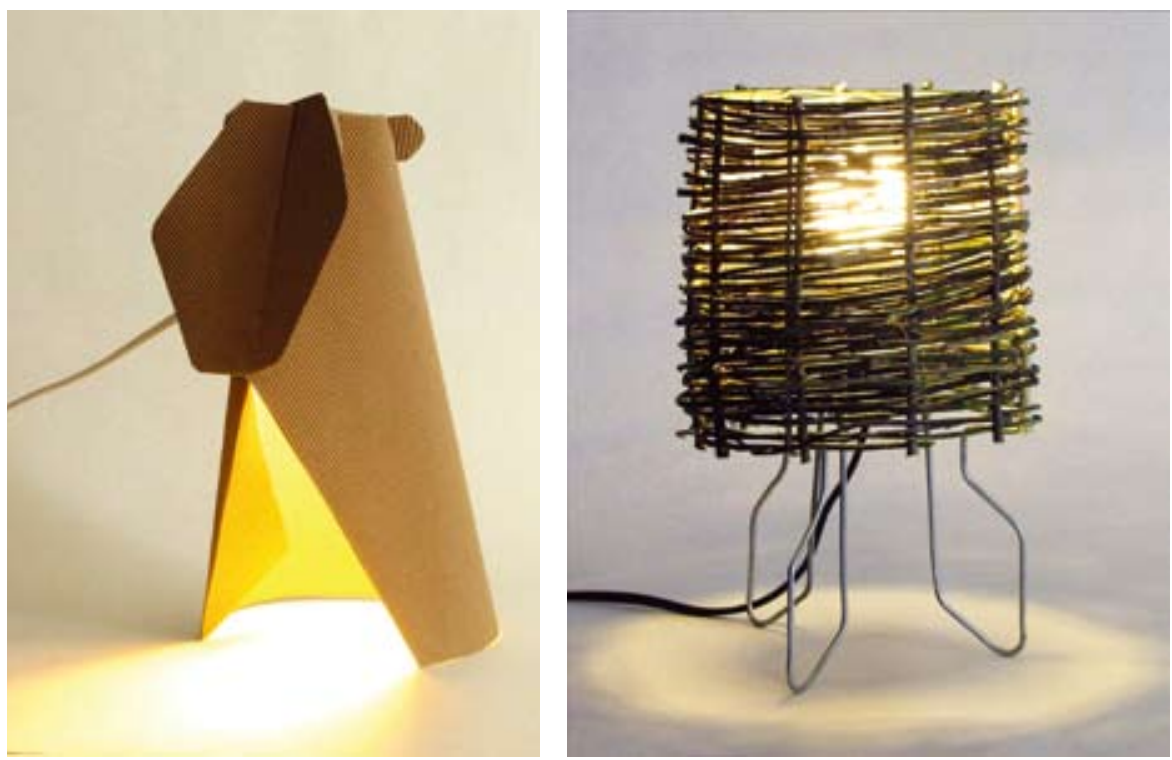

Based on the suggestions and feedback the students receive throughout the class presentations, they prepare a comprehensive written report, including visual representations, of their presentations. The following design-based projects were explored and presented by the students in the final stage of the programme.

The Tippy lighting design solution comprises four main parts: lamp, lampholder, electrical parts and cabling (Figure 1). After downloading the pattern for the shade and the attachment part from a website, the user cuts the components from a $50 \times 70 \mathrm{~cm}$ corrugated cardboard sheet. The engaging design concept involves the user in the design process. An accessible and affordable do-it-yourself design concept also allows the users to upgrade and change the lampshade and other components to increase the product's lifespan.

The Withy lighting design concept includes a galvanised wire structure that supports the electrical parts (Figure 2). The wet withies (willow stems),
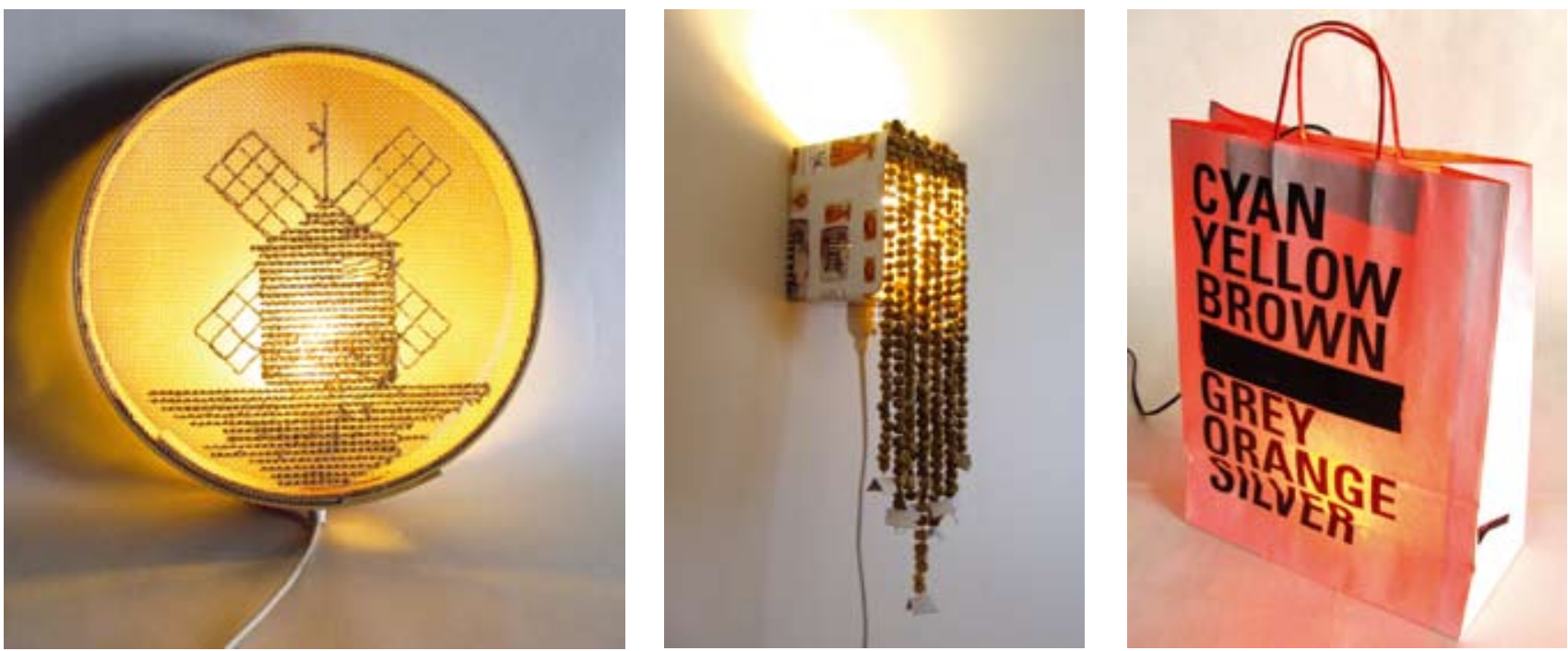
which are available locally and naturally aged, are knitted around the frame to create the lampshade. The design concept has also the potential to enable and incorporate traditional basket weaving skills at the local batchproduction scale.

The Light-mill lighting concept brings together an embroidered design pattern and a wooden sieve, having connotations with the locality (Figure 3). The embroidery is made using hemp applied to a steel mesh, stretched over a wooden sieve, and the pattern can be personalised. The design concept is an example of 'enabling design' that is highly adaptable, and can be tailored according to local tastes and preferences. By incorporating a locally made wooden sieve in the design concept, local employment and skills are utilised.

The main components of the Nest lighting concept are ready-made strings of Harmal (üzerlik in Turkish), a plant with supposed medicinal and spiritual properties that is native to the Eastern Mediterranean, as a craftbased accessory, and a re-used corrugated cardboard box (Figure 4). Harmal has various usages and connotations (e.g. providing protection from mental and physical diseases, holding spiritual value for people, etc.) in both Eastern and Western cultures. The lightshade is inspired by local Harmal crafts. Stringing Harmal into different patterns with other materials (glass beads, felt, etc.) requires drawing upon local know-how and the tacit skills or knowledge of the local people, particularly women in villages. In this regard, the 'enabling design' concept empowers local skills. The attributed meaning of Harmal is brought together with a lighting concept that leads a meaningful connection, since the spiritual value of protection becomes more explicit at night.

The Light in Heart concept brings together readily available mass-produced components (such as paper bags and electrical components), which are then re-contextualised (Figure 5). A casing made of corrugated cardboard is designed to support the light fitting, and to effectively stabilise a bag that would otherwise be discarded. Through the 'engaging' and 'evolving design concept', the locally available paper bag is transformed into a lampshade, which can also be easily re-used and replaced. Black tape is applied to conceal the brand name on the bag, which raises a question and embodies a statement on our current unsustainable consumption patterns.

\section{CONCLUSIONS AND INSIGHTS FOR THE DEVELOPMENT OF THE COURSE}

A design-centred approach for sustainability is both recent and rare in academia. Early examples in the area of product design for sustainability have mainly focussed on the environmental considerations through a Life Cycle Assessment approach. 'Product Design for Sustainability' course offers a unique design-based approach that incorporates the sustainable design considerations into the industrial design education at the graduate level in Turkey. It also aims to encourage a transition towards the integration of the sustainability considerations (i.e. increased product lifespans, localisation, effective use of resources, and product maintenance, repair and upgrade) within the context of the design education. It creates a medium for critical discussion and reflection on design and designing. The students develop innovative solutions and insights into the societal and environmental aspects of the whole product lifespan to demonstrate the potentials of product design for sustainability. 
The use of various media (e.g. seminars, class presentations of selected papers, design explorations and reflections on the design and development process, video presentations, in-class exercises and discussions) enables the sessions throughout the spring semester to be more diverse and engaging for both the instructor and the students. Almost every session is planned exclusively and specifically taking into account the scope and content of the session, and incorporating and applying various media as required. The initial sessions are constructed around lectures, video presentations and in-class discussions. In the first session, a group exercise or survey would be useful to allow a better understanding of the students' expectations, needs and their awareness about issues covered within the course context, and to better engage them in the course sessions, and would be especially useful for larger groups of graduate students. The ideal size for the class discussions and the design sessions appears to be from five to eight students, since the design critiques need to allow sufficient time for each student.

The papers presented by the students focus upon behaviour change and eco-feedback, responsible and sustainable consumption, and evolving and engaging designs for sustainability, and are selected by the students based on their research area or field of interest. This phase allows them to focus and elaborate on these topics, and evaluate the selected papers. At the mid-point of the sessions, the students present product design critiques on their selected products (e.g. small household appliances and electronics), which has emerged as an insightful exercise, since the students are able to assess selected mass-produced products based on their sustainability. This process also encourages a thorough discussion of the topics that are presented and discussed in class. The final phase of the course is the conceptual notions of sustainable products, by which the students are able to put design considerations into practice. They engage in the design and production of conceptual products, and reflect upon the whole design process. The design concepts are assessed based on sustainable design considerations, and lead to the creation of engaging, evolving and enabling designs that incorporate the needs, preferences and skills at the local batchproduction scale.

The research through design component of the course raised some challenges for the students. In particular, the electrical components of their lighting projects emerged as an issue, since the students could not intervene or change these off-the-shelf products. For most of the students, these parts were found to be not aesthetically appealing, and consequently they tended to not to reveal them in their design explorations. In their reflections of the idea generation and the design detailing phases of the design process during the class discussions, significant questions were raised regarding some of the theoretical aspects of sustainability, such as product meaning, value, localisation (integration of locally made parts), and enabling local skills. Most of the sustainability approaches appear to remain at a theoretical level, meaning that the challenge for the designer is to transform these approaches and considerations into design practice. Through a more hands-on exploratory and design-centred approach in this final phase of the course, theory and practice mutually and simultaneously inform each other in the development of sustainable products and encouraging future practices in design for sustainability. 


\section{ACKNOWLEDGEMENT}

The author would like to express her gratitude to the graduate students, Aykut Coşkun, Çiğdem Güneş, Anıl Ilgaz, Ayşegül Özbayis and Senem Turhan for their participation in and contribution to the Product Design for Sustainability course.

\section{BIBLIOGRAPHY}

BENYUS, J. (2009) Biomimicry in Action, online, http://www.ted.com/talks/ janine benyus biomimicry in action.html, accessed: 02.02.2010.

BENYUS, J. M. (1997) Biomimicry: Innovation Inspired by Nature, Morrow, New York.

CARSON, R. (1962) Silent Spring, Houghton Mifflin Company, London.

CHAPMAN, J. (2009) Design for Emotional Durability, Design Issues (25:4) 29-35.

CHAPMAN, J. (2005) Emotionally Durable Design: Objects, Experiences, and Empathy, Earthscan Publications, London.

CHAPMAN, J., GANTS, N. (2007) Designers, Visionaries and Other Stories, Earthscan Publications, London.

CLIMATIC RESEARCH UNIT (2010) Climate Change, online, www.cru.uea. ac.uk/cru/info/warming, accessed: 04.03.2011.

COOPER, T. (2005) Slower Consumption - Reflections on Product Life Spans and the "Throwaway Society", Journal of Industrial Ecology (9:1-2) 51-67.

COŞKUN, A., DOĞAN, Ç. (2010a) Post-use Design Thinking for Sustainability: A Research on an Educational Project in Industrial Design, Sustainable Innovation 10 Conference Proceedings, Rotterdam, the Netherlands; 40-6.

COŞKUN, A., DOĞAN, Ç. (2010b) Post-use Design Thinking: Presenting Insights into a Design Research for Sustainability, Sustainability in Design: NOW! Challenges and Opportunities for Design Research, Education and Practice in the XXI Century, LeNS Conference, Bangalore, India, Greenleaf Publishing, Sheffield UK, v:1; 368-81.

DALY, H. E. (1996) Beyond Growth: The Economics of Sustainable Development, Beacon Press, Boston.

DOĞAN, Ç. (2010) Reflecting on the Electronic Waste: The Case of Panel Radio Design and Its Implications for Design Education and Sustainability, Sustainable Innovation 10 Conference, 8-9 November, Rotterdam, the Netherlands; 53-60.

DOĞAN, Ç., WALKER, S. (2008) Localization - the Design and Production of Sustainable Products, International Journal of Product Development (6:3/4) 276-89.

DOĞAN, Ç. (2007) Product Design for Sustainability - Integrated Scales of Design and Production, PhD Thesis, Faculty of Environmental Design, University of Calgary, Canada.

ECOLOGICAL FOOTPRINT (2010) Ecological Footprint Calculator, http:// www.footprintnetwork.org/en/index.php/GFN/page/calculators accessed: 21.01.2010. 
FUAD-LUKE, A. (2009) Designing Together: The Power of 'We Think', 'We Design', We Make', Design Activism: Beautiful Strangeness for a Sustainable World, Earthscan Publications, London.

HAWKEN, P. (1993) The Ecology of Commerce - A Declaration of Sustainability, Harper Collins Publishers, New York.

INTERGOVERNMENTAL PANEL ON CLIMATE CHANGE (2007) IPCC Climate Change 2007: Synthesis Report, http://www.ipcc.ch/ publications and data/ar4/syr/en/mains3-2-1.html accessed: 06.03.2011.

LILLEY, D., LOFTHOUSE, V., BHAMRA, T. (2005) Towards Instinctive Sustainable Product Use, Department of Design and Technology, Loughborough University, UK, http://magpie.lboro.ac.uk:8080/ dspace-jspui/handle/2134/1013, accessed: 15.11.2008.

MANZINI, E. (2010) Design for Social Innovation for Sustainability, www. vimeo.com/9660466, accessed: 20.05.2010.

MANZINI, E. (2007) Design Research for Sustainable Social Innovation, Design Research Now, Board of International Research in Design, Part $4 ; 233-45$.

MARCHAND, A., WALKER, S., COOPER, T. (2010) Beyond Abundance: Self-Interest Motives for Sustainable Consumption in Relation to Product Perception and Preferences, Sustainability (2) 1431-47.

MARCHAND, A. (2008) Responsible Consumption and Design for Sustainability, PhD Thesis, Faculty of Environmental Design, University of Calgary, Canada.

MCDONOUGH, W., BRAUNGART, M. (2002) Cradle to Cradle: Remaking the Way We Make Things, North Point Press, New York.

MORELLI, N. (2007) Social Innovation and New Industrial Contexts, Design Issues (23:3) 3-21.

PAPANEK, V. (1999) The Green Imperative - Ecology and Ethics in Design and Architecture, Thames and Hudson, New York.

RAMAKERS, R. (2002) Less + More: Droog Design, 010 Publishers, Rotterdam.

ROBÈRT, K. H., et al. (2002) Strategic Sustainable Development - Selection, Design and Synergies of Applied Tools, The Journal of Cleaner Production (10) 197-214.

THE NATURAL STEP (2011) The System Conditions, http://www. naturalstep.org/the-system-conditions, accessed: 01.05.2011.

UNITED NATIONS FOOD AND AGRICULTURE ORGANIZATION (2010), The State of World Fisheries and Aquaculture Report, http://www. fao.org/docrep/013/i1820e/i1820e00.htm, accessed: 24.09.2011.

UNITED NATIONS WATER (2011), UN Water Statistics, online, available at: http://www.unwater.org/statistics.html accessed: 26.08.2011.

VERBEEK, P. P., KOCKELKOREN, P. (1997) Matter Matters in Van Hinte E. (ed.) Eternally Yours - Visions on Product Endurance, 010 Publishers, Rotterdam.

WALKER, S. (2011) The Spirit of Design: Objects, Environment and Meaning, Earthscan Publications, London. 
WALKER, S. (2010a) Sambo's Stones - Sustainability and Meaningful Objects, Design and Culture (2:1) 45-62.

WALKER, S. (2010b) Temporal Objects - Design, Change and Sustainability, Sustainability (2) 812-32.

WALKER, S. (2009a) After Taste - The Power and Prejudice of Product Appearance, The Design Journal (12:1) 25-40.

WALKER, S. (2009b) Touchstones - Conceptual Products for Sustainable Futures, http://www.european-futurists.org/wEnglisch/programm/ Programm2009/programm2009.php, accessed: 12.11.2009.

WALKER, S. (2006a) Creating Objects in a Saturated Culture - After the Endgame, Sustainable by Design. Earthscan Publications, London.

WALKER, S. (2006b) Reframing Design for Sustainability - Unmasking the Object, Sustainable by Design, Earthscan Publications, London.

WALKER, S., DOĞAN, Ç., MARCHAND, A. (2009) Research Through Design - The Development of Sustainable Material Cultures. Design Connexity, European Academy of Design, April 1-3, 2009, Aberdeen, Scotland, UK; 482-486.

WHITE, P., ST. PIERRE, L., BELLETIRE, S. (2009) Okala Ecological Design Guide, http://www.idsa.org/okala-ecodesign-guide, accessed: 16.01.2011.

Alındı: 13.01.2012, Son Metin: 02.07.2012

Anahtar Sözcükler: sürdürülebilirlik için ürün tasarımı; lisansüstü tasarım eğitimi; sürdürülebilirlik için tasarım odaklı yaklaşım; ürün yaşam döngüsü.

\section{PRODUCT DESIGN FOR SUSTAINABILITY: DEVELOPMENT OF A NEW GRADUATE COURSE IN INDUSTRIAL DESIGN}

“Sürdürülebilirlik için Ürün Tasarımı" dersi, Endüstri Ürünleri Tasarımı Bölümü 2011 yılı bahar döneminde, lisansüstü düzeyindeki öğrenciler için geliştirilip açılmıştır. Dersin temel amacı, ürün tasarımı ve geliştirme sürecinde, öğrencilere sürdürülebilirlik kavramının ekolojik, etik ve ekonomik boyutlarını birlikte ele alan bir yaklaşım kazandırmaktır. Bu lisansüstü ders, tasarım ve sistem odaklı güncel ve çeşitli sürdürülebilirlik yaklaşımlarının incelenmesini içerir. Ders kapsamında öğrenciler sürdürülebilirlik anlayışının, ürün tasarımı ve geliştirme alanındaki uygulanabilirlik niteliğini araştırırlar. Sürdürülebilirlik ve ürün tasarımıyla ilgili seçilen yayınların irdelenmesi, seri üretim ölçeğinde üretilen ürünlerin sürdürülebilirlik ve tasarım açısından değerlendirilmesi ve bu aşamaları temel alan çıkarımlarla, aydınlatma ürünlerinin yeniden düşünülmesi ve tasarlanması, dersin üç temel aşamasını oluşturur. Ders kapsamında tasarım odaklı bir yaklaşımla, ürünlerin temel özelliklerinin sürdürülebilirlikle ilişkisinin incelenmesi ve ürünlerin yeniden ele alınması, öğrencilere farklı bir bakış açısı sunar. Dersin önemli bir bileşeni, sürdürülebilir tasarım çözümlerinin geliştirilmesi ve süreç ve sonuçların eleştirel bir yaklaşımla paylaşılmasıdır. Öğrenciler, literatür araştırmalarını temel alan yerel değerler ve ürün yaşam döngüsünü ürün anlam ve değeriyle ilişkilendiren sürdürülebilir tasarım ölçütlerini derleyip sunarlar. Çizim ve model yapımı gibi tasarım tekniklerinden yararlanarak, aydınlatma ürün kategorisinde tasarım çözümleri geliştirirler. Öğrenciler, tasarım süreçlerini ve çözümlerini, derledikleri sürdürülebilirlik ölçütleri 
açısından değerlendirerek tasarım merkezli bir yaklaşımla sunarlar. Bu makale lisansüstü düzeyinde geliştirilmekte olan dersin süreç ve sonuçlarını sürdürülebilir tasarım eğitimi açısından değerlendirir.

ÇAĞLA DOĞAN, B.ID., M.Sc., Ph.D.

Received her B.ID. and M.Sc. in Industrial Design degrees from the METU and her Ph.D. from the Faculty of Environmental Design, University of Calgary, Canada. Her design-based research has a particular focus on product design, design education and generative research for sustainability. Currently employed as Assistant Professor in the Department of Industrial Design at METU. dcagla@metu.edu.tr 